\title{
Biodiversity of the Neotropical Larginae (Hemiptera: Pyrrhocoroidea: Largidae): Description of a new genus and new species
}

\author{
MARÍA CECILIA MELO and PABLO M. DELLAPÉ \\ Universidad Nacional de La Plata, CONICET, División Entomología, Museo de La \\ Plata, Paseo del Bosque, s/n, B1900FWA, La Plata, Buenos Aires, Argentina \\ Manuscript received on September 11, 2018; accepted for publication on January 31, 2019
}

\begin{abstract}
How to cite: MELO MC AND DELLAPÉ PM. 2019. Biodiversity of the Neotropical Larginae (Hemiptera: Pyrrhocoroidea: Largidae): Description of a new genus and new species. An Acad Bras Cienc 91: e20181237. DOI. 10.1590/0001-3765201920181237.

Abstract: A new genus of Larginae (Largidae), Parvacinocoris, is described to include a new species from Argentina and Paraguay, and P. stehliki (Doesburg) new combination, a species previously placed in Acinocoris, previously known from Surinam and Venezuela and in this paper recorded also from Brazil, Colombia and Guatemala. This new genus is similar to Acinocoris however it may be separated by the smaller size, the shorter antennae, the immaculate abdominal sterna, the shape of the parameres, and the presence of a pair of hook-like processes on the aedeagal conjunctiva. Photographs of dorsal and lateral habitus of both sexes as well as the male genitalia of the new species are included.
\end{abstract}

Key words: Parvacinocoris n. gen., P. khuru n. sp., P. stehliki n. comb., new records.

\section{INTRODUCTION}

The importance of insects is based on their diversity, ecological role, and influence on agriculture, human health, and natural resources (Scudder 2017). The number of insects described at present is more than 1 million and estimated to be 5.5 million, and about 1.6 million of them should be found in the Neotropics (Stork 2018). The Heteroptera, or true bugs (Hemiptera) represent the largest and most diverse group of hemimetabolous insects, including seven infraorders and 91 families with more than 45.000 known species (Henry 2017).

The Largidae, also known as bordered plant bugs, are a small group of heteropterans with a cosmopolitan distribution (Schuh and Slater

Correspondence to: Pablo M. Dellapé

E-mail: pdellape@ffenym.unlp.edu.ar

ORCid: https://orcid.org/0000-0002-6914-1026
1995). They are often aposematically colored and are either ground-dwelling or associated with the vegetative parts of shrubs, trees and forbs (Cassis and Gross 2002). All of the species included in the family are phytophagous, feeding on reproductive parts of plants; most of the data about hostplants of the Neotropical fauna is associated with species of Largus Spinola and the most common species of Acinocoris Hahn, A. lunaris (Gmelin) (Melo and Dellapé 2013).

The family includes 24 genera placed in two subfamilies: Physopeltinae known from the Old World, and Larginae from the New World (Dellapé and Melo 2014). The Larginae have been defined by variable characters, although most authors mentioned the non-sulcate profemur, the absence of a depression behind the buccula, and the New World distribution. This subfamily includes 15 genera that have been divided into three tribes: 
Araphini, with two genera (Arhaphe HerrichSchaeffer and Pararhaphe Henry), defined by myrmecomorphic characters; Largulini with four genera (Armilargulus Stehlík and Jindra, Largulus Hussey, Neolargulus Stehlík and Brailovsky, and Paralargulus Stehlík and Brailovsky) that share a particularly shaped pygophore; and Largini that includes nine genera (Acinocoris, Fibrenus Stål, Largus, Lecadra Signoret, Rosaphe Kirkaldy and Edwards, Stenomacra Stål, Thaumastaneis Kirkaldy and Edwards, Theraneis Spinola, and Vasarhelyecoris Brailovsky and Barrera) defined by lacking the characters found in the other tribes. Although the genera are well defined, except for the large genus Largus that likely is not monophyletic, the generic relationships have never been studied, and the placement of genera within the tribes varies, with Thaumastaneis and Vasarhelyecoris included in either Araphini or Largini, depending on the author (Schaefer 2000, 2015, Stehlik and Kment 2011, Stehlik 2013, Rosas and Brailovsky 2016).

In this contribution, we describe a new genus of Larginae to include a new species from Argentina and Paraguay, and Acinocoris stehliki Doesburg previously known from Surinam and Venezuela and in this paper also recorded from Brazil, Colombia and Guatemala. This article has been registered in the Official Register of Zoological Nomenclature (ZooBank) as http://zoobank.org/D9FEC9DCED30-44EA-99B1- D877910D8354.

\section{MATERIALS AND METHODS}

The specimens studied are deposited in the entomological collections of the Museo de La Plata, Buenos Aires, Argentina (MLP); the Museo Argentino de Ciencias Naturales "Bernardino Rivadavia, Buenos Aires, Argentina (MACN); the Instituto Fundación Miguel Lillo, San Miguel de Tucumán, Tucumán, Argentina (IFML); the National Museum of Natural History, Smithsonian
Institution, Washington, DC, USA (NMNH); and the Instituto de Biología, Universidad Nacional Autónoma de México, México City, Mexico (UNAM). All measurements are given in millimeters. The genital structures were dissected under a stereomicroscope, cleared in a $10 \% \mathrm{KOH}$ solution, washed in distilled water, and preserved in vials with glycerin. Photographs were captured using a digital camera (Micrometrics 391CU, $3.2 \mathrm{~m}$ ) mounted on a Nikon SMZ1000 stereomicroscope. Multiple focal planes were merged using Micrometrics SE Premium4 software. Plates were created and numbered in Corel Draw X8. The map was built using the QGis 3.2, localities were georeferenced with Google Earth Pro.

\section{RESULTS}

\section{Parvacinocoris, new genus}

http://zoobank.org/E50B0E48-779E-4AA5-9B5D8D0489907A36

Type species: Parvacinocoris khuru, new species

Diagnosis. Small species with abundant short silvery setae. Scape shorter than pedicel + basiflagellomere length. Profemur with 1 or 2 small spines distally, rest of legs unarmed. Abdomen dark, without large pale macula. Paramere short, with a wide shank and a large and acute blade. Presence of a posterior hook-like process on aedeagus.

Description. Small species, less than $7.5 \mathrm{~mm}$. Body with abundant short silvery setae. Body elongate, external corial margin straight. Head narrower than width of pronotum at humeral angles. Eyes pedunculate (Figs. 1, 2). Antenna relatively short, scape shorter than pedicel + basiflagellomere length. Labium reaching mesocoxae. Buccula rounded. Collar distinct. Anterior lobe of pronotum shorter than posterior lobe, never sexually dimorphic (Fig. 2). Lateral margins of pronotum rounded, not carinated. Posterior lobe of pronotum with abundant punctures, more abundant than on anterior 


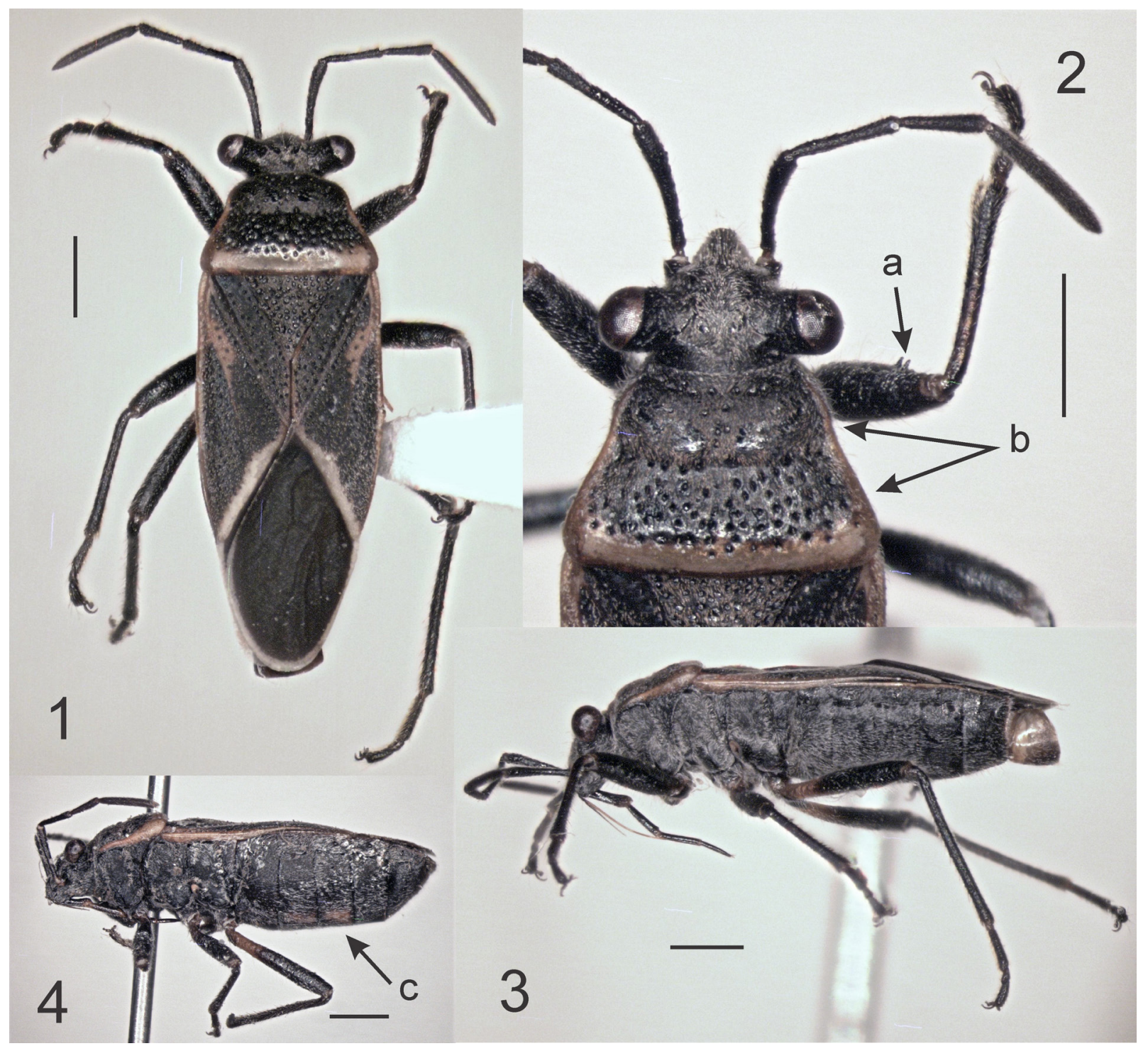

Figures 1-4 - Parvacinocoris khuru, n. sp. 1-3. Male holotype: 1. Dorsal view; 2. Detail of head and pronotum; 3. Lateral view; 4. Female paratype, lateral view. Arrows: a. Spines on profemur, b. Anterior and posterior pronotal lobes, c. Female abdomen. Scale line $1 \mathrm{~mm}$.

lobe (Fig. 2b). Metapleural scent gland auricle contrastingly colored with background (Figs. 3, 4). Procoxa unarmed. Profemur with 1 or 2 small spines distally (Fig. 2a), rest of legs unarmed. Scutellum uniformly punctate. Stridulatory structures absent on corium, metafemur or abdomen. Abdomen dark, without large pale macula. Paramere short, with a wide shank and a large and acute blade.

Etymology. The generic name is formed from the Latin parvus, meaning little, in reference to the small size, in combination with the generic name Acinocoris to denote the overall similarity of the two genera.

Distribution. Argentina, Brazil, Colombia, Guatemala, Paraguay, Surinam, and Venezuela.

Discussion. Parvacinocoris n. g. is similar to Acinocoris in general appearance, but the species included in the latter genus are larger, less setose, the antenna is longer with the scape longer than pedicel + basiflagellomere, the abdomen has large distinct 
pale maculae in both sexes, and the parameres are more elongate with a narrower shank and the blade is smaller and less acute (Fig. 12). Study of the male genitalia in the Larginae, including species of Acinocoris, shows that the parameres and aedeagus possess good generic characters. The aedeagus of P. khuru n. sp. shows remarkable differences from species in other genera (Figs. 9, 10), particularly the presence of a posterior hook-like process that is unique among the subfamily. In a preliminary phylogenetic analysis of the subfamily Larginae (unpublished data), these two genera together with Rosaphe constitute a monophyletic group supported mainly by the shape of the metapleural scent gland auricle that is rounded and raised from the metapleural sclerite; with Parvacinocoris n. $\mathrm{g}$. as the sister group of Acinocoris + Rosaphe.

The distribution of both species in this new genus (Fig. 14) shows that Parvacinocoris n. g. is mainly tropical, with $P$. khuru n. sp. also known from northeastern regions of Argentina.

\section{Parvacinocoris khuru, new species}

http://zoobank.org/F68C89A8-8155-4232-B81DDE1DA3489AD3

(Figs. 1-11, 14)

Diagnosis. Antenna black. Labium black. Hemelytra black with an orange macula on median fracture, and a wide whitish fringe adjacent to membrane. Legs black, except base of meso- and metafemora paler.

Description of holotype. Total length 6.65. Head length 1.12, head width 1.60, interocular space 1.00. Head black, covered with abundant short silvery setae, and long erect setae dorsally. Antenna black. Length of antenna: scape 1.00 , pedicel 0.70 , basiflagellomere 0.54 , distiflagellomere 1.12. Labium black, with segmental joints paler; extending to mesocoxae. Labial segments length: I 0.54, II 0.48, III 0.54, IV 0.40. Pronotum black, lateral (excepting collar area) and posterior margins orange; with abundant shorter silvery setae and scattered longer erect setae on anterior lobe. Pronotal length 1.36, width 2.08. Scutellum black, with the same setae as on pronotum. Hemelytra covered with abundant short silvery setae. Clavus black, claval commissure pale orange. Corium black, except lateral corial margins and macula on median fracture orange, and a wide whitish fringe adjacent to membrane. Membrane black, with whitish margins (Fig. 1). Legs black, except meso- and metafemora basally (Figs. 3, 4), with abundant short setae and longer semierect and erect setae. Pleurae black, except the metathoracic scent gland auricle contrastingly orange, densely covered with adpressed silvery setae. Abdomen black (Fig. 3), dorsolateral edge narrowly orange with abundant short adpressed silvery setae mixed with long erect setae. Male genitalia: Pygophore as Figs. 5, 6; paramere (Figs. 7,8) short with a wide shank and a large and acute blade; aedeagus (Figs. $9,10)$ : conjunctiva with a spinose posterior process, ductus seminis abruptly widened on distal region.

Paratypes: Similar to holotype in all aspects, except for slight differences in general coloration, e.g., some females with pale irregular markings on abdominal sternites IV and V (Fig. 4c); spermatheca rounded (Fig. 11).

Male paratypes $(n=5)$ : Total length 6.20 6.90, mean 6.52. Head length 1.04-1.20, mean 1.14 , head width 1.60-1.72, mean 1.66, interocular space 1.00-1.08, mean 1.02. Length of antenna: scape 1.00-1.06, mean 1.02, pedicel $0.76-0.84$, mean 0.79 , basiflagellomere $0.52-0.60$, mean 0.56 , distiflagellomere1.08-1.18, mean 1.14. Labial segments length: I $0.52-0.56$, mean 0.54 , II 0.52 0.58 , mean 0.55 , III $0.54-0.60$, mean 0.57 , IV 0.38 0.44 , mean 0.41 . Pronotal length $1.40-1.48$, mean 1.44, width 2.12-2.32, mean 2.23.

Female paratypes $(n=5)$ : Total length 7.20 7.40, mean 7.28. Head length 1.16-1.20, mean 1.19 , head width $1.68-1.84$, mean 1.73 , interocular space 1.04-1.12, mean 1.08. Length of antenna: 


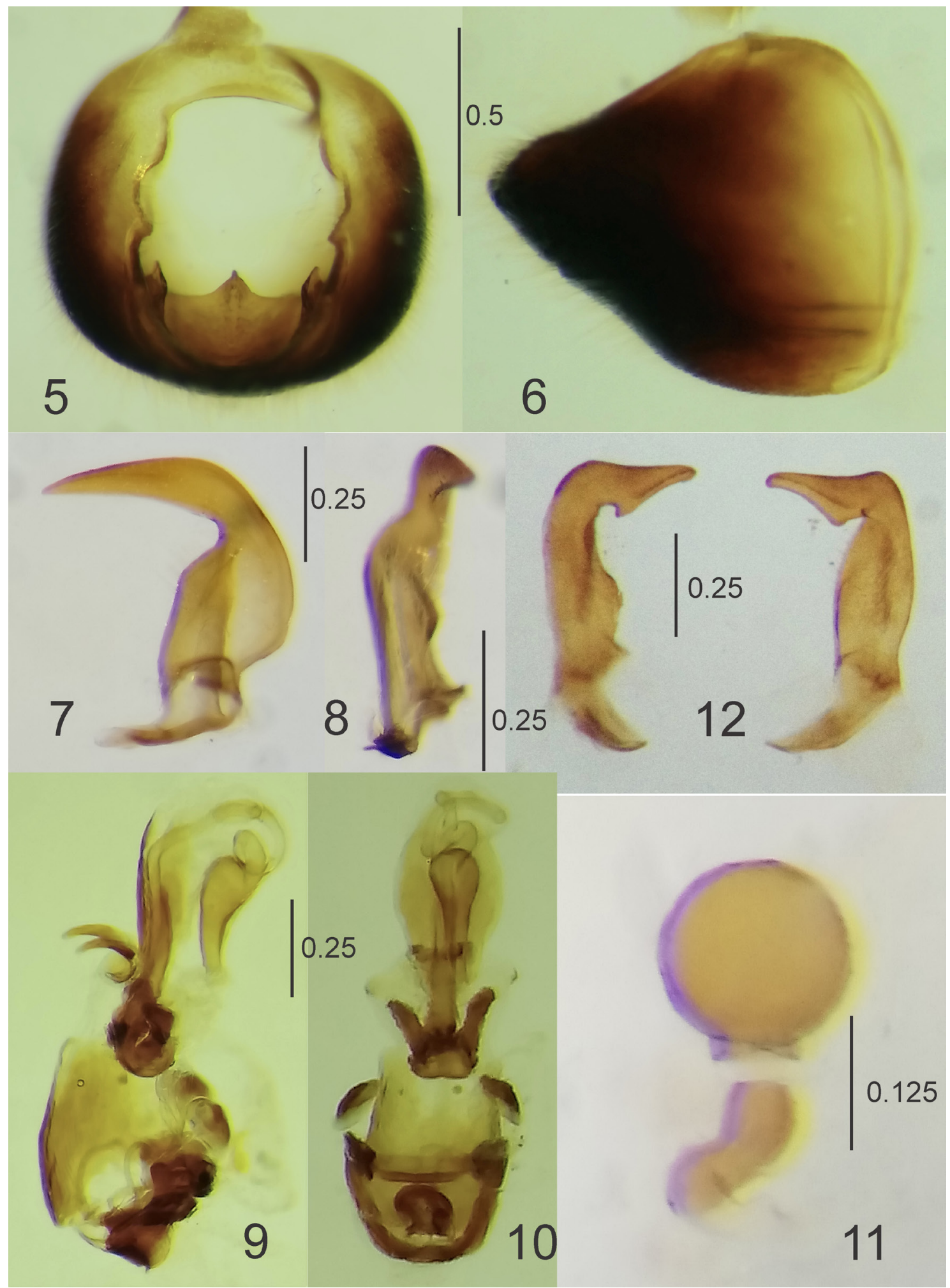

Figures 5-12 - Parvacinocoris khuru, n. sp. 5-11. 5. Pygophore, dorsal view; 6. Pygophore, lateral view; 7-8. Right paramere, 7. Lateral view, 8. Inner view; 9. Aedeagus, lateral view; 10. Aedeagus, anterior view; 11. Spermatheca; 12. Acinocoris lunaris (Gmelin), right paramere, lateral views. 
scape 1.06-1.20, mean 1.11, pedicel 0.78-0.90, mean 0.82 , basiflagellomere $0.58-0.64$, mean 0.60 , distiflagellomere1.16-1.20, mean 1.17. Labial segments length: I $0.58-0.64$, mean 0.60 , II 0.60 0.70 , mean 0.65 , III $0.60-0.70$, mean 0.65 , IV 0.42 0.48 , mean 0.44 . Pronotal length $1.48-1.68$, mean 1.55, width 2.44-2.64, mean 2.54.

Etymology. The specific epithet khuru is from the indigenous language Quechua, meaning bug or small animal. This language is spoken by the Quechua people, primarily living in the Andes and highlands of South America, where part of the new species was collected.

Host. Unknown.

Distribution. Argentina and Paraguay.

Type material. Holotype $\widehat{\sigma}$, Argentina, Salta, $12 \mathrm{Km}$ E Embarcación, antes de Pablo Lozano, 23⒔169'S 6358.429’ W, 273 m, 10-II-2016, P.M. Dellapé coll. (MLP). Paratypes: $6 \hat{\jmath} 1$, same data as holotype (MLP); $1 \hat{\jmath} 2$, Argentina, Salta, rd 53, 9 km E Padre Lozano, 275 km, 23⒓972'S 6444.449'W, 10-II-2016, T.J. Henry coll. $(\mathrm{NMNH}) ; 2$, Provincia de Salta (MACN); 1 , Corrientes, Manantiales, II-[19]46, Birabén coll. (MLP); 1 \% , Argentina, Formosa, Laguna Oca, VII[19]39, ex Denier Colln. (MLP); 1ठ2, Tucumán, Famaillá, 20-I-1921 (MACN); 1 q, Tucumán, Siambón, XII-[19]44 (IFML); 10̂, Parag.[uay], San Bernardino, 15-I-[19]39, ex Denier Colln. (MLP).

\section{Parvacinocoris stehliki (Doesburg, 1966), new combination}

(Figs. 13, 14)

Acinocoris stehliki Doesburg, 1966: 4-7 [Surinam: Afobakka, border of Suriname River (type locality); Paloemeu]

Acinocoris stehliki: Schaefer, 2000: 135-136 [Venezuela: Suapure, El Caura]

Diagnosis. Antennae: underside of scape yellow and middle parts of pedicel and basiflagellomere dark brown. Labium pale brown,

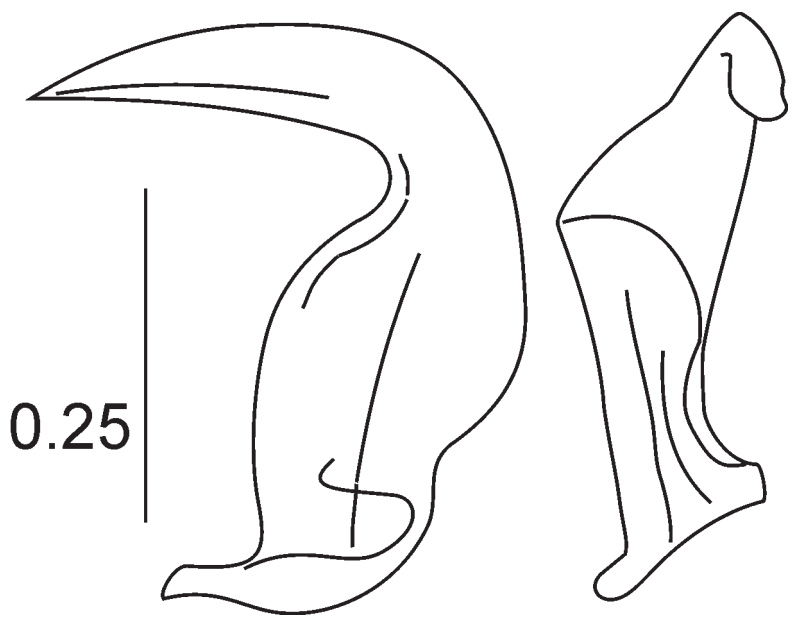

Figure 13 - Parvacinocoris stehliki (Doesburg, 1966), n. comb. Parameres. From Doesburg (1966).

with the last two segments darker. Hemelytra dull brown without conspicuous paler markings. Legs brown with dark areas at apex of femora, base and apex of tibiae and tarsi.

Host plants. Found on Solanum covered with vines (Doesburg 1966).

Distribution. Suriname, Venezuela; Brazil, Colombia and Guatemala (new records).

Specimens examined. $10 \widehat{\diamond} 8$, , Brazil, Amazonas, Rio Janauaca, $40 \mathrm{~km}$ SW Manaus, $0^{\circ} 20^{\prime} \mathrm{S}, 060^{\circ} 17^{\prime} \mathrm{W}, 10$-III-1979, Montgomery, Erwin, Sucharov, Schimmel, Krischik, Date \& Bacon colls., white water inundation forest canopy, fogged with pyrethrum, sample \#60 (NMNH); 20 2ㅇ, Brazil, Amazonas, Paraná Costa de Ilha de Curarí (Rio Solimões), $03^{\circ} 25^{\prime}$ 'S, $060^{\circ} 15^{\prime}$ W, 3 Aug. 1979, Varzea, canopy-fogging project, TRS\#01, Tray 308, Adis, Erwin, Montgomery et al. colls., white water inundation forest canopy, fogged with pyrethrum (NMNH); 10, Brazil, Amazon River, near Obidos, 13 Sept. 1930, Holts, Blake \& Agostini colls. (NMNH); 19, Colombia, Pto. Carreño, Algodín, 25 Jan. 1984, Benjamin coll. (NMNH); $1 \jmath^{\lambda}$, Guatemala, Morales, IX-1929, J.J. White, J.C. Lutz coll. (UNAM); $3 \overbrace{}^{\Uparrow} 3$, same data (NMNH); 1ð̂, Venezuela, Guarico, 19 km NW San Fdo. de Apure, 26 July 1988, C. \& L. O’Brien \& G. Wibmer (NMNH). 


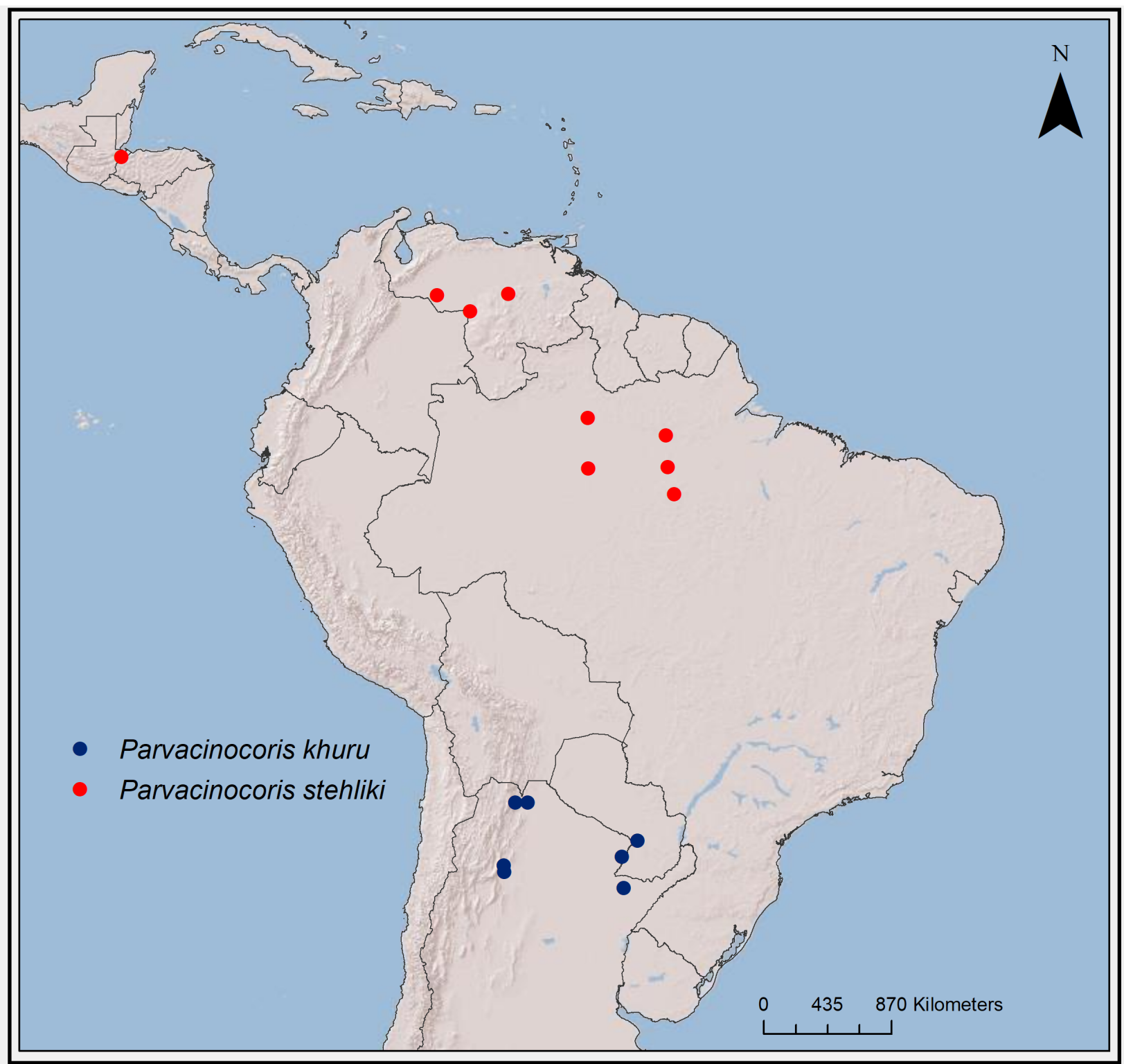

Figure 14 - Distributional map of Parvacinocoris stehliki (Doesburg, 1966), n. comb. and Parvacinocoris khuru, n. sp.

Discussion. The original description of $P$. stehliki, n. comb., agrees with all of the generic features of Parvacinocoris n. g. Doesburg's (1966) illustrations of the right paramere (Fig. 13) showing a wide shank and a large and acute blade, are similar to those of P. khuru n. sp. Both species can be separated nonetheless by the color of the antennae, labium, legs, and hemelytra. The general coloration of P. khuru n. sp. is darker, mostly black, except for an orange macula on median fracture and a wide whitish fringe adjacent to membrane, and the pale base of meso- and metafemora. In P. stehliki n. comb. the underside of the scape is yellow and the middle parts of pedicel and basiflagellomere are dark brown, the labium and the legs are paler with brown tibiae and tarsi, and the hemelytra are paler without the conspicuous markings of $P$. khuru n. sp.

Although nothing is known about the biology of these species, because of the holotype and part of the type series of $P$. khuru n. sp. were collected on the ground, it seems to be a geophilic species. 


\section{ACKNOWLEDGMENTS}

We thank Harry Brailovsky (Universidad Nacional Autónoma de México) for his hospitality and support during visiting the entomological collection of the Instituto de Biología, UNAM; and Thomas Henry (Systematic Entomology Laboratory, ARS, USDA c/o National Museum of Natural History (NMNH), Washington, DC), who collected part of the type series and lent part of the specimens used in this study, and kindly made a critical reading of the manuscript. This work was partially funded by the Consejo Nacional de Investigaciones Científicas y Técnicas (CONICET), Argentina; and the Universidad Nacional de La Plata.

\section{AUTHOR CONTRIBUTIONS}

PMD and MCM designed the study, performed the descriptions and illustrations of the species, and both contributed equally to the preparation and writing of the manuscript.

\section{REFERENCES}

CASSIS G AND GROSS GF. 2002. Hemiptera: Heteroptera (Pentatomomorpha). In: Houston WWK and Maynard GV (Eds), Zoological Catalogue of Australia. Volume 27.3B. CSIRO, Melbourne, Australia, p. 1-737.

DELLAPÉ PM AND MELO MC. 2014. Pyrrhocoroidea. In: Roig-Juñent $\mathrm{S}$ et al. (Dirs), Biodiversidad de Artrópodos Argentinos vol. III, San Miguel de Tucumán: Editorial INSUE - Universidad Nacional de Tucumán, Argentina, p. $441-450$.
DOESBURG Jr PH, van. 1966. Heteroptera of Suriname. I. Largidae and Pyrrhocoridae. Studies on the Fauna of Suriname and other Guyanas 9: $60 \mathrm{p}$.

HENRY TJ. 2017. Biodiversity of Heteroptera. In: Foottit RG and Adler PH (Eds), Insect Biodiversity: Science and Society, vol. I, $2^{\text {nd }}$ ed., John Wiley \& Sons Ltd, p. 279-335.

MELO MC AND DELLAPÉ PM. 2013. Catalogue of the Pyrrhocoroidea (Hemiptera: Heteroptera) from Argentina. Rev Soc Ent Arg 72(1-2): 55-74.

ROSAS R AND BRAILOVSKY H. 2016. Revisión del género Largus (Hemiptera: Heteroptera: Largidae) para México. Rev Mex Biodivers 87: 347-375.

SCHAEFER CW. 2000. Systematic notes on Larginae (Hemiptera: Largidae). J New York Entomol Soc 108(12): $130-145$.

SCHAEFER CW. 2015. Ch. 17. Cotton stainers (Pyrrhocoridae) and bordered plant bugs (Largidae). In: Panizzi AR and Grazia J. True Bugs (Heteroptera) of the Neotropics. Entomology in Focus 2, p. 515-535.

SCHUH RT AND SLATER JA. 1995. True Bugs of the World (Hemiptera: Heteroptera). Classification and Natural History. Cornell University Press, Ithaca and London, 336 p.

SCUDDER GGE. 2017. The importance of insects. In: Foottit RG and Adler PH (Eds) Insect Biodiversity: Science and Society, vol. I, $2^{\text {nd }}$ ed., John Wiley \& Sons Ltd, p. 9-43.

STEHLIK JL. 2013. Review and reclassification of the Old World genus Physopelta (Hemiptera: Heteroptera: Largidae). Acta Entomol Musei Natl Pragae 53(2): 505584.

STEHLIK JL AND KMENT P. 2011. Redescription of Pararhaphe and review of Arhaphe (Hemiptera: Heteroptera: Largidae) of America north of Mexico. Zootaxa 3058: 35-54.

STORK NE. 2018. How many species of insects and other terrestrial arthropods are there one Earth? Annu Rev Entomol 63: 31-45. 